\title{
Health Care Maintenance of HIV Infected Women at a Tertiary Care Center
}

\author{
Mohamed Ali Elkarouri ${ }^{1,}$, Muneerah Mohammed Albugami ${ }^{2}$, Magid A. Halim Mohamed ${ }^{3}$, \\ Munirah Abdulrahman Bin Dahham ${ }^{3}$, Yasmin Ahmed Al Twaijri ${ }^{4}$ \\ ${ }^{1}$ Department of Medicine, Section of Infectious Diseases, Security Forces Hospital, Riyadh, Saudi Arabia \\ ${ }^{2}$ Department of Medicine, King Faisal Specialist Hospital and Research Center, Riyadh, Saudi Arabia \\ ${ }^{3}$ Department of Medicine, Section of Infectious Diseases, King Faisal Specialist Hospital and Research Center, Riyadh, Saudi Arabia \\ ${ }^{4}$ Research Centre, Department of Biostatistics, Epidemiology and Scientific Computing, King Faisal Specialist Hospital and Research \\ Center, Riyadh, Saudi Arabia
}

\section{Email address:}

mohdkaro@yahoo.com (M. A. Elkarouri), mbugami@kfshrc.edu.sa (M. M. Albugami), halim@kfshrc.edu.sa (M. A. H. Mohamed), mdahham@kfshrc.edu.sa (M. A. B. Dahham), yasmin@kfshrc.edu.sa (Y. A. A. Twaijri)

${ }^{*}$ Corresponding author

\section{To cite this article:}

Mohamed Ali Elkarouri, Muneerah Mohammed Albugami, Magid A. Halim Mohamed, Munirah Abdulrahman Bin Dahham, Yasmin Ahmed Al Twaijri. Health Care Maintenance of HIV Infected Women at a Tertiary Care Center. American Journal of Internal Medicine.

Vol. 4, No. 6, 2016, pp. 101-106. doi: 10.11648/j.ajim.20160406.12

Received: October 1, 2016; Accepted: October 26, 2016; Published: November 19, 2016

\begin{abstract}
Introduction: HIV care should change from HIV focused approach to one which addresses chronic diseases, counseling, screening of non-AIDS related malignancies and immunization. Our objectives are to review standard of health maintenance services (screening, counselling and immunization) among HIV infected women and to find the prevalence of comorbid conditions. Methodology: Retrospective cohort study to review HIV infected women in HIV clinic at King Faisal Specialist Hospital and Research Center, Riyadh, Saudi Arabia (KFSH\&RC) from January 2008 to December 2012. Results: Among 103 HIV infected women, dyslipidemia accounts for 31.07\%, hypertension 16.5\%, diabetes mellitus $14.6 \%$, patients who have more than two co-morbid conditions were $24.5 \%$. Vitamin D level was requested for $93.20 \%$. HIV viral load wasn't detectable in $63.11 \%$ and antiretroviral therapy was prescribed for $99.02 \%$. The median latest CD4 lymphocyte count was 725 cells/ $\mu$ mol. Tuberculin screening test (TST) was done for $5.88 \%$. Screening mammography and Pap smear were done for $37.25 \%, 13.73 \%$ respectively. Colorectal cancer screening was not done in $96.11 \%$. Bone densitometry screening was done for $36.36 \%$. Mental status evaluation was performed for $63.73 \%$. Influenza, pneumococcal, hepatitis B virus and Human Papilloma Virus (HPV) vaccination were received by 93.20\%, 49.51\%, 17.47\% and 1.94\% respectively. Counseling for condom use was provided to $64.79 \%$ and hormonal contraception/obstetrics referral were done for $49.02 \%$. Conclusion: Our HIV clinic is providing a standard HIV focused patient care. Screening for tuberculosis, malignancies, counseling for hormonal contraception and immunization were deficient. There is high prevalence of cardiovascular risk factors among our patients. There is an urgent need to improve delivery of preventive health care to HIV-infected women.
\end{abstract}

Keywords: HIV Infected Women, Health Maintenance, Preventive Care

\section{Introduction}

Highly Active Anti-retroviral Therapy (HAART) has increased the average life expectancy of HIV patients. Morbidity and mortality have changed from opportunistic infection and AIDS-related malignancies to chronic diseases such as cardiovascular diseases and non-AIDS related malignancies (NADCs). So HIV care should change from HIV focused approach to one which addresses elements of long term infection, chronic diseases, counseling, screening of non-AIDS related malignancies and immunization [1-3].

Health Maintenance is a systematic program planned to maintain maximum function; improve quality of life and to prevent common conditions of aging. A number of HIV 
centers are moving from providing specialty care to offering general primary care. Several organizations (e.g., AAHIVM, HIV Medicine Association, the AIDS Education and Training Centers Program of the Ryan White CARE Act, Health HIV) have increased their efforts to provide up-todate clinical training for primary care providers [2-4]. Studies done on assessment of health maintenance services for HIV patients were few [3, 5-7].

HIV-infected women are at elevated risk of cervical dysplasia and cervical cancer which is highly associated with type 16 and 18 HPV infections. Despite this known risk, cervical cancer screening remains suboptimal in HIV-infected women [8]. There is no evidence that breast cancer incidence is higher among HIV-infected women than in the general population. It appears that the natural history of breast cancer in the setting of HIV infection is worse than in the general population. This may be related to a biologically more aggressive breast cancer compounded by the inability to deliver full doses of systemic anti-cancer therapies in HIV patients [8-9].

HIV-positive colorectal cancer (CRC) patients tend to be of young age, have predilection of the right side of colon and more aggressive course of $\mathrm{CRC}$, with poor outcome. The underuse of CRC screening tests in patients with HIV has important clinical implications and may represent a missed opportunity for cancer prevention [10-12].

Low bone mineral density (BMD) in HIV patients is due to a complex interaction between HIV infection and traditional osteoporosis risk factors [13, 14]. Vitamin D deficiency is common in young and postmenopausal Saudi women $[15,16]$. Vitamin D deficiency has been reported among HIV patients [17]

HIV infected women experience a higher prevalence of psychological symptoms e.g. depressive disorders, due to menopausal transition and HIV infection $[18,19]$ Also socioenvironmental factors, drug use and socioeconomic issues have a contributory role. All HIV patients should receive influenza, pneumococcal, hepatitis B virus, HPV, and Varicella
Zoster Virus vaccines. In 2013, the Infectious Diseases Society of America published guidelines for vaccination of immunocompromised hosts, including HIV patients [20]

The objectives of our study are to review standard of health maintenance services (screening, counselling and immunization) among HIV infected women and to find out the prevalence of co-morbid conditions. Up to our knowledge our study is the first in Saudi Arabia.

\section{Methodology}

A retrospective, cohort study utilized chart review of HIV infected women who received regular care in HIV clinic at King Faisal Specialist Hospital and Research Centre (KFSH \& RC) in Saudi Arabia from January 2008 to December 2012.

Statistical Analysis:

All the statistical analysis of data was done by using the software package SAS version 9.3 (Statistical Analysis System, SAS Institute Inc., Cary, NC, USA). Descriptive statistics for the continuous variables are reported as median and interquartile range, and categorical variables are summarized as frequencies and percentages. Proportions were compared by using Chisquare test or Fisher's exact test as appropriate. $\mathrm{P}$ values are considered significant if they were $<0.05$.

\section{Results}

The total number of HIV infected women attending the HIV clinic is 126 . We excluded 23 women as follows: 12 had their follow up transferred to other facility, six missing charts, four lost follow up, one deceased due to non-HIV cause. A total of 103 were included in the study. Their basic characteristics were shown in table 1 . The median age is 40 years and post menopause women were 11 (10.78\%).

Table 1. Basic characteristics of HIV infected women.

\begin{tabular}{|c|c|c|c|}
\hline Criteria Total no. $=103$ & Frequency & Percent (\%) & Median \\
\hline Current age & & & $40.0(17.0-63.0)$ \\
\hline Age when diagnosed with HIV & & & $29.0(0.1-56)$ \\
\hline Current BMI & & & $28.0(15.0-51)$ \\
\hline \multicolumn{4}{|l|}{ Marital status: } \\
\hline -Divorced & 3 & 2.91 & \\
\hline -Married & 74 & 71.84 & \\
\hline -single & 8 & 7.76 & \\
\hline -not recorded/missing & 3 & 2.91 & \\
\hline \multicolumn{4}{|l|}{ Menopause: } \\
\hline$-\mathrm{No}$ & 78 & 76.4 & \\
\hline -Not applicable & 6 & 5.88 & \\
\hline -Yes & 11 & 10.78 & \\
\hline -Not recorded/missing & 8 & 7.76 & \\
\hline \multicolumn{4}{|l|}{ Modes of transmission: } \\
\hline -Mother to fetus & 12 & 11.65 & \\
\hline -Drug abuse & 0 & 0 & \\
\hline -Accidental needle injury & 0 & 0 & \\
\hline -Traditional Higama & 0 & 0 & \\
\hline -Not recorded/missing & 10 & 9.70 & \\
\hline
\end{tabular}


Dyslipidemia accounts for 32 (31.07\%), hypertension 17 (16.5\%), diabetes mellitus $15(14.6 \%)$, more than two comorbid conditions 14 (24.5\%). Regular follow up of fasting glucose and lipid profile were done for $99.02 \%$, vitamin D level was requested for 96 (93.2\%). Co-infection with $\mathrm{HCV}$ six $(5.88 \%)$, co-infection with HBV two (1.98\%). HIV viral load wasn't detectable in $65(63.11 \%)$, antiretroviral therapy prescribed for $102(99.02 \%)$, only one patient refused to receive antiretroviral therapy. The median latest CD4 lymphocyte count was 725 cells $/ \mu \mathrm{L}$. TST was performed for six (5.88\%). Screening mammography and Pap smear were done for $19(37.25 \%), 14(13.73 \%)$ respectively. CRC screening (fecal occult, colonoscopy, and flexiblesigmoidoscopy) was not done for 99 (96.11\%) Bone densitometry screening for osteoporosis was performed for four $(36.36 \%)$ of those who were indicated. Mental status evaluation was performed for 65 (63.73\%). Influenza, pneumococcal, hepatitis B virus and HPV vaccination were received by $96(93.2 \%), 51(50.50 \%), 18(18 \%)$ and two patients $(1.94 \%)$ respectively. Counseling for condom use (safe sex) was provided to $46(64.79 \%)$, hormonal contraception/obstetrics referral for 50 (49.02\%). Pregnancy counseling was provided to $50(49.02 \%)$. For pregnancy, $31.07 \%$ of our patients had experienced pregnancy. Details of results are in table 2 .

Table 2. Health maintenance services among HIV infected women.

\begin{tabular}{|c|c|c|c|c|c|c|}
\hline Comorbid conditions: & $\begin{array}{l}\text { Frequency } \\
\text { Total no.=103 }\end{array}$ & $\begin{array}{l}\text { Percent } \\
\text { (\%) }\end{array}$ & Median & Comorbid conditions: & $\begin{array}{l}\text { Frequency } \\
\text { Total no.=103 }\end{array}$ & $\begin{array}{l}\text { Percent } \\
(\%)\end{array}$ \\
\hline Dyslipidemia & 32 & 31.07 & & Bone densitometry: & & \\
\hline Hypertension & 17 & 16.50 & & $-\mathrm{No}$ & 4 & 50.00 \\
\hline Diabetes mellitus & 15 & 14.56 & & -Yes & 4 & 50.00 \\
\hline Osteoarthritis & 8 & 7.77 & & -Not indicated & 95 & 92.23 \\
\hline $\mathrm{HCV}$ & 6 & 5.88 & & Pap smear: & & \\
\hline Br. Asthma & 6 & 5.88 & & $-\mathrm{No}$ & 77 & 75.49 \\
\hline HAV & 4 & 3.92 & & -Not applicable (single) & 9 & 8.82 \\
\hline Heart failure & 3 & 2.94 & & -not recorded/missing & 3 & 1.96 \\
\hline Renal disease & 3 & 2.94 & & -Yes & 14 & 13.73 \\
\hline $\mathrm{HBV}$ & 2 & 1.98 & & Mental status evaluation & 65 & 63.73 \\
\hline Cancer (lymphoma) & 2 & 1.98 & & Immunization: & & \\
\hline IHD & 1 & 0.97 & & Influenza: & & \\
\hline Osteoporosis & 1 & 0.97 & & $-\mathrm{No}$ & 7 & 6.80 \\
\hline COPD & 1 & 0.97 & & -Yes & 96 & 93.20 \\
\hline Previous CVA & 0 & 0 & & Pneumococcal: & & \\
\hline Liver cirrhosis & 0 & 0 & & $-\mathrm{No}$ & 50 & 48.54 \\
\hline More than 1 Comorbid condition: & & & & -Yes & 51 & 49.51 \\
\hline & & & & -Not recorded/missing & 2 & 1.94 \\
\hline$>2$ & 14 & 24.5 & & $-\mathrm{No}$ & 101 & 98.06 \\
\hline Investigations: & & & & -Yes & 2 & 1.94 \\
\hline Fasting glucose & 102 & 99.02 & & HBV: & & \\
\hline Lipid profile & 102 & 99.02 & & $-\mathrm{No}$ & 82 & 79.61 \\
\hline & & & & -Yes & 18 & 17.47 \\
\hline Vit D level & 96 & 93.20 & & -Not recorded/ missing & 3 & 2.91 \\
\hline HIV Care: & & & & Counselling: & & \\
\hline Plasma HIV load detectable: & & & & Condom use: & & \\
\hline$-\mathrm{No}$ & 65 & 63.11 & & $-\mathrm{No}$ & 3 & 4.23 \\
\hline -Yes & 37 & 35.92 & & -Not applicable & 32 & 30.39 \\
\hline -not recorded/missing & 1 & 0.97 & & -not recorded/missing & 22 & 21.57 \\
\hline Latest CD4 lymphocyte count & & & $\begin{array}{l}725.0 \\
(23.0-2162.0)\end{array}$ & -yes & 46 & 64.79 \\
\hline Antiretroviral therapy: & & & & Hormonal contraception & ns/gyne referral: & \\
\hline$-\mathrm{No}$ & 1 & 0.98 & & -No & 2 & 1.96 \\
\hline -Yes & 102 & 99.02 & & -Not applicable & 30 & 29.41 \\
\hline Screening: & & & & -not recorded/missing & 21 & 20.38 \\
\hline TST & 6 & 5.88 & & -Yes & 50 & 49.02 \\
\hline Mammography: & & & & Pregnancy (Counselling): & & \\
\hline$-\mathrm{No}$ & 32 & 62.75 & & $-\mathrm{No}$ & 2 & 2.76 \\
\hline -Not applicable & 52 & 50.48 & & Not applicable & 30 & 29.41 \\
\hline -Yes & 19 & 37.25 & & -not recorded/missing & 21 & 19.61 \\
\hline Colonoscopy: & & & & -Yes & 50 & 69.44 \\
\hline -No & 99 & 96.11 & & Preonancy. & & \\
\hline -Yes & 0 & 0 & & riegnancy. & & \\
\hline -not recorded/ missing & 4 & 3.88 & & Got pregnant: & & \\
\hline Flexible sigmoidoscopy: & & & & $-\mathrm{NO}$ & 46 & 46.46 \\
\hline$-\mathrm{No}$ & 100 & 97.08 & & -Not applicable & 21 & 20.39 \\
\hline -Yes & 0 & 0 & & -not recorded/missing & 4 & 3.88 \\
\hline
\end{tabular}




\begin{tabular}{|c|c|c|c|c|c|c|}
\hline Comorbid conditions: & $\begin{array}{l}\text { Frequency } \\
\text { Total no.=103 } \\
\end{array}$ & $\begin{array}{l}\text { Percent } \\
(\%)\end{array}$ & Median & Comorbid conditions: & $\begin{array}{l}\text { Frequency } \\
\text { Total no. }=103 \\
\end{array}$ & $\begin{array}{l}\text { Percent } \\
(\%)\end{array}$ \\
\hline $\begin{array}{l}\text {-not recorded/missing } \\
\text { Faecal occult: }\end{array}$ & 3 & 2.91 & & -Yes & 32 & 32.32 \\
\hline -No & 101 & 98.05 & & & & \\
\hline -Yes & 0 & 0 & & & & \\
\hline -not recorded/missing & 2 & 1.94 & & & & \\
\hline
\end{tabular}

\section{Discussion}

Our HIV clinic is providing a standard HIV focused patient care. The prevalence of cardiovascular risk factors like dyslipidemia, hypertension and diabetes mellitus are high among our patients. In the literature, dyslipidemia was reported in $22 \%$ of HIV patients, diabetes mellitus $17 \%$, hypertension $40 \%$ and Depression $22 \%$. [21]

Dyslipidemia in HIV patient could be due to side effects from HAART therapy mainly protease inhibitors (PI). Studies on the use of PI and cardiovascular risk were controversy, some concluded increased risk, others claimed no increased risk [22-27]. Data collection on Adverse events of anti-HIV Drugs (D:A:D) stated that HAART was associated $26 \%$ relative risk increase in the rate of myocardial infarction per year exposure during the first 4-6 years [24]. In Saudi Arabia the prevalence of diabetes was $14.8 \%$ for males and $11.7 \%$ for females in 2013 survey [28], the prevalence of hypertension was $17.7 \%$ for males and $12.5 \%$ for females [29], the prevalence of hypercholesterolemia was $9.5 \%$ for males and $7.3 \%$ for females, while the prevalence of obesity was higher among females than males, $33.5 \%$ and $24.1 \%$, respectively [30]. Almost half of women are physically inactive, while $29 \%$ had low levels of physical activity [28-30].

Majority of women in our study were young and only minority were postmenopausal.

On reviewing the literature, in the post-HAART era, numerous international epidemiological studies have shown that rates of NADC srose by more than 3 -fold, while the rates of AIDS-defining cancers (non- Hodgkin's lymphoma and Kaposi's sarcoma) declined 3-fold in the same period from 1995 to 2005 [31]. In our study, malignancy occurred in two patients $(1.98 \%)$. At one study comparing HIV positive and HIV negative women; mammography was done for $24.3 \%$ of HIV positive women and $62.3 \%$ of HIV negative women [5]. Another study reported $41.5 \%$ [3]. In our study it was done for $37.25 \%$.

Colonoscopy, flexible sigmoidoscopy and fecal occult screening for colorectal cancer were not done in any of our patients. One study showed CRC screen in a form of colonoscopy was performed for 54.4\% [5]. Another study reported $16.8 \%$ for colonoscopy and $24.3 \%$ for fecal occult screening [3]. A third study reported 10\% colonoscopy [6]. Public health strategies and additional research are needed to determine if screening HIV patients for colorectal cancer should include younger patients and involve the entire colon. Cervical cancer screening was done for $13.73 \%$ of our patients, other studies reported $59 \%$ and $56.8 \%[3,6]$.
TST was performed for $5.88 \%$ of our patients. One study reported TST screening was done for 54.5\% [3]. Another study reported $63 \%$ [6]. Aggressive screening for tuberculosis in HIV-infected patients is recommended, based upon the high risk of reactivation of latent tuberculosis, even at relatively high CD4 counts [32]. IDSA/ HIV Medicine association 2013 recommended upon initiation of care, HIVinfected patients without a history of tuberculosis or a prior positive tuberculosis, screening test should be done for Mycobacterium tuberculosis infection by either TST or by an interferon- $\gamma$ release assay (IGRA) [32]. Repeat testing is recommended in patients with advanced HIV disease who initially had negative TST or IGRA results.

Pneumococcal, HPV and hepatitis B vaccination were provided to minimal number of patients. In one study, pneumococcal vaccination was achieved in $87 \%$, influenza vaccination $64.4 \%$ and $\mathrm{HB}$ vaccination $66 \%$ [3]. It has been noticed the lower rates of hepatitis $B$ vaccination locally and internationally [34, 35].

Vitamin D level was requested for $93.20 \%$ of women. This reflects good awareness of the higher incidence of vitamin D deficiency in our population [16]. Bone densitometry screening for osteoporosis was performed for $36.36 \%$ of those who were indicated. Several studies have consistently shown increased prevalence of low BMD among HIVinfected women nearing the age of menopause [36-38]. Comparison of fracture prevalence in HIV andnon-HIV patients according to gender and age group showed fracture prevalence is increased in HIV patients [39]. There are currently no changes in osteoporosis recommendations based on HIV status or HAART use. Early screening of this population may be needed because of earlier menopause.

The US Preventive Services Task Force (USPSTF) recommends screening of all adults for depression, although the optimal screening interval is unknown. Our HIV clinic provided mental status evaluation to $63.73 \%$ of patients. In another studyit was provided for $82.8 \%$ [6, 40-42]. Counseling for condom use (safe sex) is reported in $45.1 \%$ of patients. Other study reported 33.9\% [6].

\section{Conclusion}

Our HIV clinic is providing a standard HIV focused patient care. Screening for tuberculosis, malignancies, counseling for hormonal contraception and immunization were deficient. This is recognized internationally in similar studies. The prevalence of cardiovascular risk factors is high among our patients. There is an urgent need to improve delivery of preventive health care to HIV-infected women.

We recommend to increase the awareness of physicians 
attending HIV clinics on preventive measures and management of chronic medical conditions by: continuous medical education, initiate check lists in charts, computer generated notification, better documentation, share management with other needed specialties e.g. general medicine, psychiatry, obstetrics/gynecology.

Set up of proper primary care services nation-wise will provide continuity and accessibility.

The limitations of our study are insufficient documentation; counseling might be done but not documented; unrecoverable information's due to lack of legibility of hand writing; missing charts and study being done in one center might not represent other centers.

\section{Conflict of Interest}

The author has no conflicts of interest in the research, no support from any organization for the submitted work; no financial relationships with any organizations that might have an interest in the submitted work; no other relationships or activities that could appear to have influenced the submitted work.

\section{Acknowledgments}

The authors are grateful to Mr. Abdelmoneim Eldali from BESC, Research Center at KFSH\&RC for his effort in the statistical analysis of our study.

\section{References}

[1] Chu C, Selwyn PA. An epidemic in evolution: the need for new models of HIV care in the chronic disease era. J Urban Health. 2011 Jun; 88 (3): 556-66.

[2] Fultz SL, Goulet JL, Weissman S, Rimland D, Leaf D, Gibert C, Rodriguez-Barradas MC, Justice AC. Differences between infectious diseases-certified physicians and general medicinecertified physicians in the level of comfort with providing primary care to patients. Clin Infect Dis. 2005 Sep 1; 41 (5): 738-43.

[3] Sheth AN, Moore RD, Gebo KA. Provision of general and HIV-specific health maintenance in middle aged and older patients in an urban HIV clinic. AIDS Patient Care STDS. 2006 May; 20 (5): 318-25.

[4] Aberg JA, Gallant JE, Ghanem KG, Emmanuel P, Zingman BS, Horberg MA; Infectious Diseases Society of America. Primary care guidelines for the management of persons infected with HIV: 2013 update by the HIV medicine association of the Infectious Diseases Society of America. Clin Infect Dis. 2014 Jan; 58 (1): e1-34.

[5] Momplaisir F, Mounzer K, Long JA. Preventive cancer screening practices in HIV-positive patients. AIDS Care. 2014 Jan; 26 (1): 87-94.

[6] Simonsen SE, Kepka D, Thompson J, Warner EL, Snyder M, Ries KM. Preventive health care among HIV positive women in a Utah HIV/AIDS clinic: a retrospective cohort study. BMC Womens Health. 2014 Mar 4; 14 (1): 37.

[7] Grulich AE, van Leeuwen MT, Falster MO, Vajdic CM.
Incidence of cancers in people with HIV/AIDS compared with immunosuppressed transplant recipients: a meta-analysis. Lancet. 2007 Jul 7; 370 (9581): 59-67.

[8] Rahangdale L, Sarnquist C, Yavari A, Blumenthal P, Israelski D. Frequency of cervical cancer and breast cancer screening in HIV-infected women in a county-based HIV clinic in the Western United States. J Womens Health (Larchmt). 2010 Apr; 19 (4): 709-12.

[9] Latif N, Rana F, Guthrie T. Breast cancer and HIV in the era of highly active antiretroviral therapy: two case reports and review of the literature. Breast J. 2011 Jan-Feb; 17 (1): 87-92

[10] Wasserberg N, Nunoo-Mensah JW, Gonzalez-Ruiz C, Beart RW Jr, Kaiser AM. Colorectal cancer in HIV-infected patients: a case control study. Int J Colorectal Dis. 2007 Oct; 22 (10): 1217-21.

[11] Reinhold JP, Moon M, Tenner CT, Poles MA, Bini EJ. Colorectal cancer screening in HIVinfected patients 50 years of age and older: missedopportunities for prevention. Am J Gastroenterol. 2005 Aug; 100 (8): 1805-12.

[12] Christopher Chapman, David M. Aboulafia, Bruce J. Dezube, Liron Pantanowitz. Human Immunodeficiency VirusAssociated Adenocarcinoma of the Colon: Clinicopathologic Findings and Outcome. Clinical Colorectal Cancer. October 2009 Volume 8, Issue 4, Pages 215-219

[13] Arnsten JH, Freeman R, Howard AA, Floris-Moore M, Lo Y, Klein RS. Decreased bone mineral density and increased fracture risk in aging men with or at risk for HIV infection. AIDS. 2007 Mar 12; 21 (5): 617-23.

[14] McComsey GA, Tebas P, Shane E, Yin MT, Overton ET, Huang JS, Aldrovandi GM, Cardoso SW, Santana JL, Brown TT. Bone disease in HIV infection: a practical review and recommendations for HIV care providers. Clin Infect Dis. 2010 Oct 15; 51 (8): 937-46.

[15] Elsammak MY, Al-Wossaibi AA, Al-Howeish A, Alsaeed J. High prevalence of vitamin D deficiency in the sunny Eastern region of Saudi Arabia: a hospital-based study. East Mediterr Health J. 2011 Apr; 17 (4): 317-22.

[16] Al-Turki HA, Sadat-Ali M, Al-Elq AH, Al-Mulhim FA, AlAli AK. 25-Hydoxyvitamin D levels among healthy Saudi Arabian women. Saudi Med J. 2008 Dec; 29 (12): 1765-8.

[17] Adeyemi OM, Agniel D, French AL, Tien PC, Weber K, Glesby MJ, Villacres MC, Sharma A, Merenstein D, Golub ET, Meyer W, Cohen M. Vitamin D deficiency in HIVinfected and HIV-uninfected women in the United States. J Acquir Immune DeficSyndr. 2011 Jul 1; 57 (3): 197-204.

[18] Fantry LE, Zhan M, Taylor GH, Sill AM, Flaws JA. Age of menopause and menopausal symptoms in HIV-infected women. AIDS Patient Care STDS. 2005 Nov; 19 (11): 703-11.

[19] Ferreira CE, Pinto-Neto AM, Conde DM, Costa-Paiva L, Morais SS, Magalhães J. Menopause symptoms in women infected with HIV: prevalence and associated factors. Gynecol Endocrinol. 2007 Apr; 23 (4): 198-205.

[20] Rubin LG, Levin MJ, Ljungman P, Davies EG, Avery R, Tomblyn M, Bousvaros A, Dhanireddy S, Sung L, Keyserling H, Kang I; Infectious Diseases Society of America. 2013 IDSA clinical practice guideline for vaccination of the immunocompromised host. Clin Infect Dis. 2014 Feb; 58 (3): 309-18. 
[21] Fultz SL, Goulet JL, Weissman S, Rimland D, Leaf D, Gibert C, Rodriguez-Barradas MC, Justice AC. Differences between infectious diseases-certified physicians and general medicinecertified physicians in the level of comfort with providing primary care to patients. Clin Infect Dis. 2005 Sep 1; 41 (5): 738-43.

[22] Coplan PM, Nikas A, Japour A, Cormier K, Maradit-Kremers $\mathrm{H}$, Lewis $\mathrm{R}, \mathrm{Xu} \mathrm{Y}$, DiNubile MJ. Incidence of myocardial infarction in randomized clinical trials of protease inhibitorbased antiretroviral therapy: an analysis of four different protease inhibitors. AIDS Res Hum Retroviruses. 2003 Jun; 19 (6): 449-55.

[23] Klein D, Hurley LB, Quesenberry CP Jr, Sidney S. Do protease inhibitors increase the risk for coronary heart disease in patients with HIV-1 infection? J Acquir Immune DeficSyndr. 2002 Aug 15; 30 (5): 471-7.

[24] Writing Committee: N Friis-Moller, CA Sabin, R Weber, A d'ArminioMonforte, WM El-Sadr, P Reiss, R Thiebaut, L Morfeldt, S De Wit, C Pradier, G Calvo, MG Law, O Kirk, AN Phillips, JD Lundgren. Combination Antiretroviral Therapy and the Risk of Myocardial Infarction. The Data Collection on Adverse Events of Anti-HIV Drugs (D:A:D) Study Group. N Engl J Med. 2003; 349 (21); 1993-2003.

[25] Mary-Krause M, Cotte L, Simon A, Partisani M, Costagliola D; Clinical Epidemiology Group from the French Hospital Database. Increased risk of myocardial infarction with duration of protease inhibitor therapy in HIV-infected men. AIDS. 2003 Nov 21; 17 (17): 2479-86.

[26] Triant VA, Lee H, Hadigan C, Grinspoon SK. Increased acute myocardial infarction rates and cardiovascular risk factors among patients with human immunodeficiency virus disease. J Clin Endocrinol Metab. 2007 Jul; 92 (7): 2506-12.

[27] Bozzette SA, Ake CF, Tam HK, Chang SW, Louis TA. Cardiovascular and cerebrovascular events in patients treated for human immunodeficiency virus infection. N Engl J Med. 2003 Feb 20; 348 (8): 702-10

[28] El Bcheraoui C, Memish ZA, Tuffaha M, Daoud F, Robinson M, Jaber S, Mikhitarian S, Al Saeedi M, AlMazroa MA, Mokdad AH, Al Rabeeah AA. Hypertension and its associated risk factors in the kingdom of saudi arabia, 2013: a national survey. Int J Hypertens. 2014; 2014: 564679.

[29] Basulaiman M, El Bcheraoui C, Tuffaha M, Robinson M, Daoud F, Jaber S, Mikhitarian S, Wilson S, Memish ZA, Al Saeedi M, AlMazroa MA, Mokdad AH. Hypercholesterolemia and its associated risk factors-Kingdom of Saudi Arabia, 2013. Ann Epidemiol. 2014 Nov; 24 (11): 801-8.

[30] Memish ZA, El Bcheraoui C, Tuffaha M, Robinson M, Daoud F, Jaber S, Mikhitarian S, Al Saeedi M, AlMazroa MA, Mokdad AH, Al Rabeeah AA. Obesity and associated factors-Kingdom of Saudi Arabia, 2013. Prev Chronic Dis. 2014 Oct 9; 11: E174.

[31] Deeken JF, Tjen-A-Looi A, Rudek MA, Okuliar C, Young M, Little RF, Dezube BJ. The rising challenge of non-AIDS- defining cancers in HIV-infected patients. Clin Infect Dis. 2012 Nov; 55 (9): 1228-35.

[32] Markowitz N, Hansen NI, Hopewell PC, Glassroth J, Kvale PA, Mangura BT, Wilcosky TC, Wallace JM, Rosen MJ, Reichman LB. Incidence of tuberculosis in the United States among HIV-infected persons. The Pulmonary Complications of HIV Infection Study Group. Ann Intern Med. 1997 Jan 15; 126 (2): 123-32.

[33] Gerald H. Mazurek, MD, John Jereb, MD, Andrew Vernon, MD, Phillip LoBue, MD, Stefan Goldberg, MD, Kenneth Castro, MD. Updated guidelines for using interferon gamma release assays to detect Mycobacterium tuberculosis infection-United States, 2010. MMWR Recomm Rep 2010; 59: $1-25$.

[34] Alhuraiji A, Alaraj A, Alghamdi S, Alrbiaan A, Alrajhi AA. Viral hepatitis B and C in HIV-infected patients in Saudi Arabia. Ann Saudi Med. 2014 May-Jun; 34 (3): 207-10

[35] Kellerman SE, Hanson DL, McNaghten AD, Fleming PL. Prevalence of chronic hepatitis $\mathrm{B}$ and incidence of acute hepatitis B infection in human immunodeficiency virusinfected subjects. J Infect Dis. 2003 Aug 15; 188 (4): 571-7.

[36] Arnsten JH, Freeman R, Howard AA, Floris-Moore M, Santoro N, Schoenbaum EE. HIV infection and bone mineral density in middle-aged women. Clin Infect Dis. 2006 Apr 1; 42 (7): 1014-20.

[37] Yin M, Dobkin J, Brudney K, Becker C, Zadel JL, Manandhar M, Addesso V, Shane E. Bone mass and mineral metabolism in HIV+ postmenopausal women. Osteoporos Int. 2005 Nov; 16 (11): $1345-52$.

[38] Yin MT, McMahon DJ, Ferris DC, Zhang CA, Shu A, Staron R, Colon I, Laurence J, Dobkin JF, Hammer SM, Shane E. Low bone mass and high bone turnover in postmenopausal human immunodeficiency virus-infected women. J ClinEndocrinol Metab. 2010 Feb; 95 (2): 620-9.

[39] Triant VA, Brown TT, Lee H, Grinspoon SK. Fracture prevalence among human immunodeficiency virus (HIV)infected versus non-HIV-infected patients in a large U.S. healthcare system. J ClinEndocrinolMetab. 2008 Sep; 93 (9): 3499-504.

[40] Komiti A, Judd F, Grech P, Mijch A, Hoy J, Williams B, Street A, Lloyd JH. Depression in people living with HIV/AIDS attending primary care and outpatient clinics. Aust N Z J Psychiatry. 2003 Feb; 37 (1): 70-7.

[41] Jeannette R. Ickovics, Merle E. Hamburger, David Vlahov, Ellie E. Schoenbaum, Paula Schuman, Robert J. Boland, Janet Moore. Mortality, CD4 Cell Count Decline, and Depressive Symptoms Among HIV-Seropositive Women. Longitudinal Analysis From the HIV Epidemiology Research Study. JAMA. 2001; 285 (11): 1466-1474.

[42] Morrison MF, Petitto JM, Ten Have T, Gettes DR, Chiappini MS, Weber AL, Brinker-Spence P, Bauer RM, Douglas SD, Evans DL. Depressive and anxiety disorders in women with HIV infection. Am J Psychiatry. 2002 May; 159 (5): 789-96. 